\title{
Implementasi Peraturan Daerah Tentang Kawasan Tanpa Rokok Di Dinas Kesehatan Kota Yogyakarta
}

\author{
Rin Agustina A'yuni ${ }^{1 *}$ Nasrullah2 \\ ${ }^{1,2}$ Program Studi Hukum, Fakultas Hukum, Universitas Muhammadiyah Yogyakarta, Indonesia \\ *Korespondensi: rin.agustina.2016@law.umy.ac.id
}

\section{Artikel Info}

Submitted: 20-03-2020

Reviewed: 26-03-2020

Revised: 30-03-2020

Accepted: 31-03-2020

DOI: $10.18196 / \mathrm{mls} . v 2 i 2.11487$

\begin{abstract}
Abstrak
Merokok berdampak buruk bagi kesehatan tubuh manusia sehingga menghambat pembangunan dibidang kesehatan. Hal ini menjadi dasar Pemerintah Kota Yogyakarta untuk membuat kebijakan yang mengatur tentang kawasan tanpa rokok yang tertuang dalam Peraturan Daerah Kota Yogyakarta Nomor 2 Tahun 2017 tentang Kawasan Tanpa Rokok. Masalah dari Implementasi Peraturan Daerah tentang Kawasan Tanpa Rokok di Dinas Kesehatan Kota Yogyakarta yaitu masih
\end{abstract} adanya pegawai yang merokok di kawasan tanpa rokok karena belum diterapkannya sanksi yang tegas untuk pelaku yang melanggar Peraturan Daerah serta tingkat pengawasan masih lemah. Tujuan dalam penelitian ini yaitu untuk mengetahui implementasi dan kendala yang dihadapi oleh Pemerintah Daerah dalam penerapan kawasan tanpa rokok. Penelitian ini menggunakan metode penelitian empiris melalui wawancara kepada narasumber dan mengumpulkan dokumen-dokumen terkait. Berdasarkan penelitian tersebut dapat disimpulkan bahwa implementasi peraturan daerah di Dinas Kesehatan Kota Yogyakarta sudah cukup berhasil, karena pada umumnya para pegawai cukup patuh terhadap peraturan daerah kawasan tanpa rokok, meskipun masih ada beberapa pegawai kantor yang melanggar peraturan tersebut. Dinas Kesehatan Kota Yogyakarta sudah ada area khusus merokok, namun di tempat lain yang ditentukan dalam peraturan daerah kawasan tanpa rokok belum disediakan ruangan khusus merokok karena terkendala oleh keterbatasan anggaran. Penegakan hukum belum ditegakkan secara tegas, sanksi penegakan saat ini hanya sebatas teguran lisan saja.

Kata Kunci: implementasi, kawasan tanpa rokok, peraturan daerah.

\section{Pendahuluan}

Kesehatan merupakan hak asasi yang wajib dipenuhi oleh negara untuk setiap warganya. Salah satu perilaku masyarakat Indonesia yang berdampak negatif bagi kesehatan individu dan lingkungan adalah merokok. Merokok selain berbahaya bagi diri sendiri juga membahayakan kesehatan orang lain yang memiliki hak untuk menghirup udara yang bersih dan terhindar dari segala bahan cemaran yang dikeluarkan oleh asap rokok orang lain. ${ }^{1}$ Kebiasaan merokok sudah meluas di seluruh Indonesia, termasuk Kota Yogyakarta. Hampir semua kelompok masyarakat di Kota Yogyakarta, termasuk dikalangan anak dan remaja memiliki kebiasaan merokok. Hal ini memberi makna bahwa masalah merokok di Kota Yogyakarta perlu mendapat perhatian yang serius.

\footnotetext{
1 Andi Mariani, 2009, "Pemberlakuan Larangan Merokok di Tempat Umum dan Hak Atas Derajat Kesehatan Optimal”, (Program Pascasarjana Magister Hukum Kesehatan Universitas Katolik Soegijapranata Semarang), h. 1.
} 
Seperti yang kita ketahui, rokok merupakan salah satu yang membuat lingkungan sekitar kita menjadi tidak sehat, karena asap yang dihasilkannya mengandung banyak zat berbahaya yang dapat mengakibatkan tercemarnya lingkungan serta mengganggu kesehatan penikmatnya maupun orang disekitarnya. Sebagian besar orang bisa meninggal dikarenakan mengonsumsi rokok dengan berlebih. Awalnya memang tidak terasa sakit, tetapi semakin lama seseorang mengonsumsi rokok, maka akan banyak timbul berbagai penyakit dalam tubuhnya. ${ }^{2}$

Perlu dibuat kebijakan untuk memberikan perlindungan terhadap paparan asap rokok, namun dengan tetap memperhatikan hak asasi pengguna rokok sendiri. Sebagaimana diketahui bahwa aktivitas merokok juga merupakan salah satu bentuk hak asasi manusia dan tidak ada seorang pun yang berhak melarangnya. Namun demikian bagi perokok sendiri, kebebasan untuk merokok ini tidak serta merta dapat membuat seorang perokok dapat merokok dimana saja yang pada akhirnya mengganggu kebebasan orang lain. Sehingga untuk menyeimbangkan hak masing-masing orang diperlukan peraturan yang mengatur tentang hak kesehatan seseorang tanpa harus melanggar hak orang lain untuk merokok. ${ }^{3}$

Kawasan Tanpa Rokok adalah ruangan atau area yang dinyatakan dilarang untuk kegiatan merokok atau kegiatan memproduksi, menjual, mengiklankan dan/atau mempromosikan produk tembakau. Kawasan Tanpa Rokok ditetapkan antara lain fasilitas pelayanan kesehatan, tempat proses belajar mengajar, tempat anak bermain, tempat ibadah, angkutan umum, tempat kerja, tempat umum dan tempat lain yang ditetapkan. Pasal 25 ayat (1) Peraturan Daerah Nomor 2 Tahun 2017 tentang Kawasan Tanpa Rokok menerangkan bahwa seseorang yang melanggar peraturan tersebut akan dikenakan sanksi berupa kurungan paling lama 1 (satu) bulan atau denda paling banyak Rp.7.500.000,00 (tujuh juta lima ratus ribu rupiah).

Bahaya ancaman asap rokok bagi kesehatan masyarakat mulai menjadi fokus yang penting bagi pemerintah di beberapa daerah. Salah satunya Pemerintah Kota Yogyakarta yang telah memberlakukan Peraturan Daerah Kota Yogyakarta Nomor 2 Tahun 2017 tentang Kawasan Tanpa Rokok. Dalam Peraturan Daerah Kota Yogyakarta Nomor 2 Tahun 2017 tentang Kawasan Tanpa Rokok, ditetapkan tempat-tempat yang termasuk Kawasan Tanpa Rokok meliputi: Fasilitas pelayanan kesehatan, Tempat proses belajar mengajar, Tempat anak bermain, Tempat ibadah, Angkutan umum, Tempat kerja dan Tempat umum. Kawasan Tanpa Rokok (KTR) adalah ruangan atau

\footnotetext{
${ }^{2}$ Ade Resty Ambar Wati, 2017, "Penerapan Kawasan Tanpa Rokok berdasarkan Peraturan Daerah Kota Metro Nomor 4 Tahun 2014”, Jurnal Fakultas Hukum Universitas Lampung, Vol. 4, No. 2, h. 1.

${ }^{3}$ Yana Agus Setianingsih, dkk, 2016, "Pelaksanaan Kebijakan Kawasan Tanpa Rokok (KTR) Sebagai Bagian Dari Perilaku Hidup Bersih dan Sehat (PHBS) di Lingkungan Pendidikan (Studi Kasus Pada STIKES di Kota Semarang)", Jurnal Hukum Kesehatan, Vol. 1, No. 1, h. 107.
} 
area yang dinyatakan dilarang untuk kegiatan merokok atau kegiatan memproduksi, menjual, mengiklankan dan/atau mempromosikan produk tembakau. ${ }^{4}$

Tujuan dari Peraturan Daerah Kota Yogyakarta Nomor 2 Tahun 2017 tentang Kawasan Tanpa Rokok adalah untuk memberikan perlindungan yang efektif dari bahaya asap rokok bagi perokok aktif maupun perokok pasif, memberikan ruang dan lingkungan yang bersih dan sehat bagi masyarakat yang bebas dari asap rokok, melindungi kesehatan masyarakat secara umum dari dampak buruk merokok baik secara langsung maupun tidak langsung, dan menurunkan angka perokok dan mencegah perokok pemula.

Satuan Kerja Perangkat Daerah (SKPD) yang berkewajiban melakukan pembinaan terhadap pelanggaran adalah Pemerintah Kota Yogyakarta dan Dinas Kesehatan Kota Yogyakarta. Pemerintah Kota Yogyakarta dan Dinas Kesehatan memiliki kewajiban untuk memberikan sosialisasi dan pendidikan tentang bahaya merokok terhadap masyarakat, melakukan pemantauan dan evaluasi, serta melaksanakan pembinaan dan pengawasan dari pelaksanaan Kawasan Tanpa Rokok. Satuan Polisi Pamong Praja juga berperan penting dalam penegakan Kawasan Tanpa Rokok. Selain itu, pengelola Kawasan Tanpa Rokok wajib memasang tanda larangan merokok serta menyediakan smoking area di tempat yang sudah ditetapkan sebagai Kawasan Tanpa Rokok.

Meski Kota Yogyakarta sudah memiliki peraturan daerah (Perda) tentang kawasan tanpa rokok, fakta di lapangan menunjukkan bahwa terdapat beberapa lokasi yang sudah diterapkan aturan kawasan tanpa rokok terhadap masyarakat namun belum terlaksana dengan baik karena kurangnya pengetahuan terkait peraturan daerah tersebut dan kurangnya kesadaran dari masyarakat sendiri untuk menjaga kesehatan tubuh dalam mengurangi penggunaan rokok. Aturan tersebut sangat mudah dilanggar tanpa ada konsekuensi yang tegas dari penegak Kawasan Tanpa Rokok. Salah satu tempat yang termasuk Kawasan Tanpa Rokok yaitu Dinas Kesehatan Kota Yogyakarta yang merupakan tempat kerja. Termasuk dalam Kawasan Tanpa Rokok karena dikhawatirkan kegiatan merokok itu sendiri akan mengakibatkan terganggunya aktivitas pekerjaan dan mengganggu kesehatan pekerja.

Implementasi Kawasan Tanpa Rokok juga mesti didukung dengan kepatuhan dan kepedulian masyarakat mengenai kebijakan tersebut, sehingga Kebijakan pemerintah tentang area bebas rokok nantinya akan mampu menyelamatkan nasib perokok pasif melihat banyaknya jumlah perokok aktif yang ada. Berdasarkan uraian di atas, maka peneliti tertarik untuk melakukan penelitian dengan judul "Implementasi Peraturan Daerah tentang Kawasan Tanpa Rokok di Dinas Kesehatan Kota Yogyakarta”. Hal ini penting dilakukan karena akan memberikan gambaran nyata mengenai Implementasi Kebijakan Kawasan Tanpa Rokok di tempat kerja yaitu Dinas Kesehatan Kota

\footnotetext{
${ }^{4}$ Meysi Ariska, 2017, "Implementasi Peraturan Daerah Kabupaten Bintan Nomor 1 Tahun 2016 tentang Kawasan Tanpa Rokok”, Jurnal Ilmu Administrasi Negara, Vol. 5, No. 1, h. 46-47.
} 
Yogyakarta. Gambaran tersebut dapat dijadikan bahan pertimbangan dan acuan untuk menyelesaikan masalah terkait implementasi Kebijakan Kawasan Tanpa Rokok.

\section{Metode Penelitian}

Penelitian ini menggunakan merode penelitian empiris, yaitu menggunakan faktafakta empiris yang didapat melalui wawancara maupun perilaku nyata yang dilakukan melalui pengamatan langsung. Dalam penelitian ini menggunakan data primer yang diperoleh dengan wawancara langsung kepada narasumber dan menggunakan data sekunder yang diperoleh dari hasil penelaahan kepustakaan atau literatur yang berkaitan materi peneliti. Narasumber dalam penelitian ini adalah Ibu drg. Arumi Wulansari, MPH., selaku Kepala Seksi Promosi dan Pemberdayaan Masyarakat di Dinas Kesehatan Kota Yogyakarta. Lokasi penelitian ini dilakukan di Dinas Kesehatan Kota Yogyakarta. Hasil data dari penelitian akan dianalisis secara deskriptif-kualitatif, mengorganisasikan data yang banyak melalui hasil pengumpulan data dengan rapi, sistematis dan mengumpulkan data selengkap mungkin. ${ }^{5}$

\section{Hasil dan Pembahasan}

Kota Yogyakarta berkedudukan sebagai Ibu Kota Propinsi Daerah Istimewa Yogyakarta dan merupakan satu-satunya daerah tingkat II yang berstatus Kota di samping 4 daerah tingkat II lainnya yang berstatus Kabupaten. Kota Yogyakarta memiliki luas sekitar 32,5 $\mathrm{km}^{2}$ atau 1,02\% dari luas wilayah Provinsi Daerah Istimewa Yogyakarta. Jarak terjauh dari Utara ke Selatan kurang lebih 7,5 km dan dari Barat ke Timur kurang lebih 5,6 km. Kota Yogyakarta yang terletak di daerah dataran lereng aliran Gunung Merapi memiliki kemiringan lahan yang relatif datar antara 0-2\% dan berada pada ketinggian rata-rata $114 \mathrm{~m}$ dari permukaan air laut (dpa). Sebagian wilayah dengan luas 1.657 hektar terletak pada ketinggian kurang dari $100 \mathrm{~m}$ dan sisanya pada ketinggian antara 100-199 mdpa yang sebagian besar jenis tanahnya adalah regosol. Secara administratif Kota Yogyakarta memiliki luas wilayah $32,50 \mathrm{~km}^{2}$.

Implementasi kebijakan publik dikatakan berhasil jika apa yang diharapkan dari adanya kebijakan tersebut dapat diraih, yang dicapai melalui pelaksanaan yang sesuai dengan ketentuan yang telah ditetapkan. Hasilnya adalah bahwa apa yang menjadi tujuan tidaklah melenceng dari tujuan semula. Dalam suatu proses implementasi kebijakan terkadang tidak selancar apa yang diperkirakan sebelumnya. Dalam banyak kasus, seringkali implementasi kebijakan menemui suatu kendala atau tantangan, terutama karena adanya berbagai kepentingan. Implementasi kebijakan publik bukanlah suatu hal yang mudah. Oleh karenanya, belum tentu suatu kebijakan publik dapat diimplementasikan dengan baik. Kadangkala apa yang sudah ditetapkan dalam kebijakan publik berbeda dengan keadaan di lapangan dan hasil yang dicapai.

\footnotetext{
${ }^{5}$ M. Syamsudin, 2007, Operasional Penelitian Hukum, Edisi pertama, Raja Grafindo Persada, Jakarta, h. 134.
} 
Keberhasilan implementasi kebijakan dapat dilihat dari adanya kesesuaian antara pelaksanaan/penerapan kebijakan dengan desain, tujuan, sasaran dari kebijakan itu sendiri dan memberikan hasil yang positif bagi pemecahan permasalahan yang dihadapi. Asumsi yang dapat dibangun mengenai konsep keberhasilan kebijakan adalah bahwa semakin tinggi derajat kesesuaiannya, maka akan semakin tinggi pula peluang keberhasilan kinerja implementasi kebijakan untuk menghasilkan out put yang telah digariskan. ${ }^{6}$

Pemerintah Daerah Kota Yogyakarta membuat kebijakan tentang Kawasan Tanpa Rokok karena komitmennya untuk memberikan perlindungan hukum bagi warga kotanya dari paparan asap rokok orang lain, memberikan ruang dan lingkungan yang bersih dan sehat bagi masyarakat dan melindungi kesehatan masyarakat perokok maupun bukan perokok dari dampak buruk asap rokok baik langsung maupun tidak langsung. Sejak diterbitkannya Peraturan Daerah Kota Yogyakarta Nomor 2 Tahun 2017 tentang Kawasan Tanpa Rokok, Pemerintah Daerah bersama seluruh komponen masyarakat bertanggung jawab untuk mengamankan dan melaksanakan Peraturan Daerah tentang Kawasan Tanpa Rokok (KTR). Pemerintah Daerah bekerja sama dengan para pemilik, pengelola, manajer, pimpinan, dan penanggungjawab Kawasan Tanpa Rokok setempat untuk memastikan bahwa semua orang tahu apa yang harus mereka lakukan untuk menjadikan Kawasan Tanpa Rokok secara penuh, tahu dimana orang tidak boleh merokok dan dimana boleh merokok. ${ }^{7}$

Dinas Kesehatan Kota Yogyakarta merupakan tempat kerja atau area yang dinyatakan dilarang untuk kegiatan merokok atau kegiatan memproduksi, menjual, mengiklankan dan/atau mempromosikan produk tembakau. Larangan merokok di Dinas Kesehatan Kota Yogyakarta sebagai perlindungan yang efektif dari bahaya asap rokok, memberikan ruang dan lingkungan yang bersih bagi masyarakat serta melindungi kesehatan masyarakat secara umum dari dampak buruk merokok baik langsung maupun tidak langsung. Semua pihak yang berada di lingkungan Dinas Kesehatan Kota Yogyakarta mulai dari pegawai pemerintah maupun seluruh pengunjung yang ada di Dinas Kesehatan Kota Yogyakarta ikut berperan dalam mentaati peraturan yang dibuat untuk mencapai Kawasan Tanpa Rokok. Sehingga petugas keamanan atau pegawai pemerintah wajib memberitahukan adanya larangan merokok di kawasan Dinas Kesehatan Kota Yogyakarta apabila masih ditemukannya pengunjung yang merokok.

Berdasarkan hasil wawancara dengan Ibu drg. Arumi Wulansari, MPH., selaku Kepala Seksi Promosi dan Pemberdayaan Masyarakat di Dinas Kesehatan Kota Yogyakarta bahwa Dinas Kesehatan Kota Yogyakarta sudah menerapkan Kawasan Tanpa Rokok. Penerapan Kawasan Tanpa Rokok di Dinas Kesehatan Kota Yogyakarta diberlakukan sejak Maret 2018 dan diberlakukan kepada seluruh pegawai kedinasan

\footnotetext{
${ }^{6}$ Tangkilisan, 2003, Kebijakan Publik yang Membumi, Konsep, Strategi dan Kasus, Lukman Offset dan YPAPI, Yogyakarta, h. 31.

${ }^{7}$ Widyastuti Soerojo, dkk, 2011, Pengawasan/Penegakan Hukum Kawasan Tanpa Rokok,,TCSC-IAKMI, Palembang, h. 6-7.
} 
yang ada didalamnya. Dalam pelaksanaannya Dinas Kesehatan Kota Yogyakarta melakukan 2 cara dalam menerapkan Peraturan Daerah tentang Kawasan Tanpa Rokok yaitu Sosialisasi dan Penerapan Peraturan. Dinas Kesehatan Kota Yogyakarta melakukan sosialisasi dan penyampaian informasi selama 1 tahun yang dilakukan oleh perwakilan dari UPD dan Pemerintah Kota Yogyakarta. Penerapan Peraturan mengenai Kawasan Tanpa Rokok dengan memasang Banner dan Plang yang bertuliskan tentang Kawasan Tanpa Rokok di Dinas Kesehatan Kota Yogyakarta. ${ }^{8}$

Sosialisasi merupakan syarat utama sejak sebelum Peraturan Daerah Kawasan Tanpa Rokok dirumuskan sampai tercapainya perubahan norma sosial bahwa "Merokok di Ruang Publik Tertutup adalah Tidak Normal, Tidak Etis dan memalukan". Masyarakat perlu dilibatkan dalam seluruh proses pengembangan kebijakan Peraturan Daerah Kawasan Tanpa Rokok untuk memahami bahaya mengisap asap rokok orang lain. Hak untuk mendapat perlindungan hukum dalam bentuk Peraturan Daerah yang mengikat secara hukum. Sosialisasi saja tidak menjamin kepatuhan. Diperlukan sanksi hukum mulai dari yang paling ringan berbentuk teguran lisan dan tertulis sampai dengan denda dan pencabutan izin usaha yang ditetapkan melalui sidang Tindak Pidana Ringan. Tujuannya untuk menimbulkan efek jera dan membentuk kebiasaan. Walaupun demikian, sanksi hukum bukan bertujuan untuk menghukum karena pelanggaran bukan bersifat kriminal tetapi untuk pembinaan dan lebih bersifat edukatif. Sosialisasi bertujuan untuk meningkatkan derajat kesehatan, pengetahuan, pemahaman, kesadaran, kemauan dan kemampuan masyarakat Kota Yogyakarta untuk senantiasa membiasakan hidup sehat. ${ }^{9}$

Dinas Kesehatan Kota Yogyakarta sudah menerapkan Peraturan Daerah Kota Yogyakarta Nomor 2 Tahun 2017 tentang Kawasan Tanpa Rokok dan sudah disediakan beberapa tempat khusus untuk merokok, namun masih banyak pegawai maupun pengunjung kantor yang belum mengetahui Peraturan Daerah tersebut dan masih banyak yang merokok tidak pada tempat khusus merokok yang disediakan. Dinas Kesehatan Kota Yogyakarta merupakan kawasan tempat kerja yang seharusnya para pegawai mengetahui Peraturan Daerah tentang Kawasan Tanpa Rokok tersebut. ${ }^{10}$ Menerapkan suatu Peraturan Daerah tidak semudah mengimplementasikannya, oleh sebab itu diperlukan suatu faktor yang dapat mempengaruhi terimplementasinya suatu peraturan. Bahwa faktor-faktor yang mendukung implementasi kebijakan/peraturan adalah:

1) Komunikasi

\footnotetext{
${ }^{8}$ Hasil wawancara dengan responden drg. Arumi Wulansari, MPH., selaku Kepala Seksi Promosi dan Pemberdayaan Masyarakat di Dinas Kesehatan Kota Yogyakarta, pada hari Kamis tanggal 30 April 2020, pukul 11.00 WIB.

${ }^{9}$ Ibid, h. 11.

${ }^{10}$ Amalia Lathifah, 2018, "Implementasi Peraturan Walikota Yogyakarta Nomor 2 Tahun 2015 tentang Kawasan Tanpa Rokok”, (Repository Universitas Islam Negeri Sunan Kalijaga Yogyakarta), h. 5-6.
} 
Komunikasi sangat menentukan keberhasilan pencapaian tujuan dari implementasi kebijakan publik, implementasi yang efektif terjadi apabila para pembuat keputusan sudah mengetahui apa yang akan mereka kerjakan. Faktor yang pertama ini mempunyai peran yang penting dalam implementasi suatu kebijakan. Sebuah kebijakan harus dikomunikasikan antara pembuat kebijakan dengan pelaksana kebijakan. Pelaksana kebijakan kawasan tanpa asap rokok dalam hal ini adalah Dinas Kesehatan. Pelaksana mempunyai tugas untuk menyampaikan informasi mengenai kebijakan kawasan tanpa rokok kepada seluruh masyarakat selaku obyek kebijakan. Komunikasi harus disampaikan dengan jelas dan akurat agar mudah dimengerti dan berjalan sesuai dengan tujuan kebijakan Kawasan Tanpa Rokok di Dinas Kesehatan Kota Yogyakarta.

Proses komunikasi belum begitu berpengaruh dalam Implementasi Kebijakan Kawasan Tanpa Rokok. Hal tersebut karena walaupun pemerintah sudah gencar melakukan sosialisasi dan pemasangan tanda kawasan tanpa rokok, tetapi masih ditemukan perokok di Dinas Kesehatan Kota Yogyakarta. Hal tersebut dibuktikan dengan adanya hasil survei yang dilakukan oleh Dinas Kesehatan Kota Yogyakarta.

\section{2) Sumber daya}

Sumber daya yang dimaksud dalam penelitian ini adalah tersedianya sumber daya manusia yang akan menjadi tim khusus satuan tugas (satgas) penegak dan pengawas kawasan tanpa rokok serta adanya peran dari pegawai di Dinas Kesehatan Kota Yogyakarta. Selain itu sumber daya lainnya seperti adanya anggaran dana serta fasilitasfasilitas penunjang kawasan tanpa rokok seperti tempat khusus untuk merokok, papan informasi larangan merokok, poster larangan merokok, surat edaran larangan merokok dan lain-lain yang menunjang kawasan tanpa rokok di Dinas Kesehatan Kota Yogyakarta.

\section{3) Sikap}

Sikap atau komitmen dari pelaksana kebijakan dibutuhkan dalam implementasi kebijakan. Komitmen yang kuat dari pelaksana kebijakan dapat mensukseskan implementasi kebijakan, untuk itu tuntutan komitmen pada pelaksana kebijakan harus kuat dan penuh dedikasi terhadap pelaksanaan sebuah kebijakan. Sikap yang dimaksud dalam penelitian ini adalah adanya dukungan dari pegawai kantor terhadap penerapan kawasan tanpa rokok di Dinas Kesehatan Kota Yogyakarta. ${ }^{11}$

\section{4) Struktur Birokrasi}

Struktur birokrasi mempunyai pengaruh dalam implementasi kebijakan. Standar operasional prosedur (SOP) dibuat untuk mempermudah impelementasi kebijakan dan memberi pedoman kepada pelaksana kebijakan. Dalam struktur birokrasi diperlukannya pembagian tugas tanggung jawab, kegiatan atau program pada beberapa unit kerja yang

\footnotetext{
${ }^{11}$ A.Ikram Rifqi, 2017, "Implementasi Peraturan Daerah Kota Makassar Nomor 4 Tahun 2013 tentang Kawasan Tanpa Rokok di Universitas Hasannudin", (Repository Universitas Hasannudin Makassar), h. 64.
} 
sesuai dengan bidangnya masing-masing. Adanya hal tersebut maka implementasi akan lebih efektif karena dilaksanakan oleh organisasi yang berkompeten dan kapabel. Struktur birokrasi mempengaruhi keberhasilan kebijakan karena melibatkan banyak pihak didalamnya.

Implementasi kebijakan kawasan tanpa rokok di Dinas Kesehatan Kota Yogyakarta, terdapat hubungan yang bermakna antara pengetahuan kebijakan kawasan tanpa rokok dengan implementasi kebijakan. Seseorang yang memiliki pengetahuan tidak baik terhadap kebijakan kawasan tanpa rokok pasti kepatuhannya berbeda dibandingkan dengan seseorang yang benar-benar paham terhadap kebijakan tersebut. Oleh karena itu, agar kebijakan kawasan tanpa rokok tersebut dapat berjalan sesuai dengan yang diharapkan, kebijakan larangan merokok hendaknya selalu dilakukan monitoring atau pengawasan dan membuat sanksi-sanksi yang lebih tegas lagi oleh pihak pengambil keputusan.

Sudah ada Tim Monitoring dan Evaluasi dalam pengimplementasian kawasan tanpa rokok . Bila tanpa sistem monitoring yang baik maka efektivitas Kawasan Tanpa Rokok sering kali dipertanyakan. Kawasan tanpa rokok dianggap masih sebatas papan nama yang dipasang di wilayah tertentu tanpa tahu apakah cukup efektivitas atau tidak. Sehingga disinilah diperlukan sebuah monitoring untuk melihat efektivitas kawasan tanpa rokok dari waktu ke waktu. Pengawasan kawasan tanpa rokok juga diawasi dari perwakilan masyarakat, perwakilan organisasi masyarakat, perwakilan akademisi, perwakilan Majelis Ulama Indonesia, perwakilan Pemberdayaan dan Kesejahteraan Keluarga, dan Muhammadiyah Tobacco Control Center. Kegiatan ini bertujuan untuk mengetahui monitoring dan evaluasi pada implementasi Peraturan Daerah Kota Yogyakarta Nomor 2 Tahun 2017 tentang Kawasan Tanpa Rokok. Metode yang digunakan dalam kegiatan ini adalah monitoring implementasi Peraturan Daerah di tempat yang tersebut meliputi penerapan Peraturan Daerah, pemasangan tanda peringatan yang sesuai, ada/tidaknya pelanggaran dan upaya sosialisasi Peraturan Daerah.

Pemerintah Kota Yogyakarta telah melakukan upaya-upaya penegakan peraturan berupa upaya represif dan upaya preventif yang dilakukan oleh Dinas Kesehatan Kota Yogyakarta dan Satuan Polisi Pamong Praja Kota Yogyakarta untuk melaksanakan penegakan Peraturan Daerah Nomor 2 Tahun 2017 tentang Kawasan Tanpa Rokok di Dinas Kesehatan Kota Yogyakarta. Upaya preventif yaitu berupa pencegahan pelanggaran Kawasan Tanpa Rokok dengan kegiatan berupa sosialisasi, pembinaan dan pemberian pedoman, serta monitoring dan evaluasi.

Upaya preventif yang pertama adalah melalui aturan-aturan yang membatasi aktivitas merokok. Pengaturan Kawasan Tanpa Rokok di Kota Yogyakarta secara umum diatur dalam Peraturan Daerah Kota Yogyakarta Nomor 2 Tahun 2017 tentang Kawasan Tanpa Rokok. Sanksi administratif berupa denda yang termuat didalam Pasal 25 ayat (1) Peraturan Daerah Kawasan Tanpa Rokok ini secara nominal sangat jauh jika 
dibandingkan dengan beberapa Peraturan Daerah Kawasan Tanpa Rokok di daerah lain seperti jabodetabek dan salah satu dasar pembentukan perda tersebut yaitu Pasal 199 ayat 2 Undang-Undang Nomor 36 Tahun 2009 tentang Kesehatan yaitu, Setiap orang yang dengan sengaja melanggar kawasan tanpa rokok sebagaimana dimaksud dalam Pasal 115 didenda paling banyak Rp.50.000.000,- (lima puluh juta rupiah). Dalam hal sanksi bagi pimpinan badan, jenis sanksi administratif yang digunakan ialah denda administratif yang apabila dilanggar sebanyak 3 kali sanksi selanjutnya adalah pencabutan izin usaha.

Sanksi selanjutnya yaitu sanksi bagi pengelola atau penaggung jawab yang terdapat pada Pasal 25 ayat (2) Peraturan Daerah Kawasan Tanpa Rokok berbunyi, Pengelola atau penanggung jawab Kawasan Tanpa Rokok pada tempat kerja dan tempat umum yang tidak menyediakan tempat khusus merokok sebagaimana dimaksud dalam Pasal 17 ayat (2) dipidana kurungan paling lama 1 (satu) bulan atau denda paling banyak Rp.7.500.000,00 (tujuh juta lima ratus ribu rupiah). Yang dimaksud pengelola atau penanggung jawab dalam pasal tersebut adalah badan/lembaga yang ditunjuk walikota sebagai tim pengawas serta pembina daripada Peraturan Daerah Kawasan Tanpa Rokok yang dimuat dalam Pasal 17 Peraturan Daerah Kawasan Tanpa Rokok.

Meski telah diatur mengenai sanksinya, namun dalam Peraturan Daerah tersebut tidak diatur secara jelas mengenai lembaga dan proses penegakan hukum terkait pelanggaran di lapangan, disisi lain dengan denda yang tergolong rendah tersebut dianggap tidak akan memberikan efek jera dan hanya akan membuka peluang bagi praktek-praktek Korupsi Kolusi dan Nepotisme (KKN). Oleh sebab itu proses Penegakan Hukum Peraturan Daerah Kota Yogyakarta tentang Kawasan Tanpa Rokok tersebut belum dapat berjalan sebagaimana mestinya sebagai akibat pasal-pasal dalam Peraturan Daerah mengenai penegakan hukumnya belum mengatur secara jelas, dalam kata lain terdapat kekaburan norma (vogue van normen). ${ }^{12}$

Selain Peraturan Daerah Kawasan Tanpa Rokok, pengaturan terkait kawasan tanpa rokok di Kota Yogyakarta juga terdapat pada Peraturan Walikota (PERWALI) Kota Yogyakarta No. 17 Tahun 2016 tentang Perubahan Atas Peraturan Walikota Yogyakarta No. 12 Tahun 2015 tentang Kawasan Tanpa Rokok yang memuat pengecualian terkait dengan kegiatan menjual, mengiklankan dan mempromosikan produk tembakau boleh dilakukan oleh kantor milik pribadi/swasta sebagaimana dimaksud dalam Pasal 11 huruf $\mathrm{b}$ bagi Agen/Distributor produk tembakau serta industri/pabrik sebagaimana dimaksud dalam Pasal 11 huruf c yang memproduksi produk tembakau boleh melakukan kegiatan menjual, mengiklankan dan mempromosikan produk tembakau.

Upaya preventif yang kedua dalam menegakkan sanksi administratif terhadap pelanggaran kawasan tanpa rokok di Kota Yogyakarta selanjutnya ialah dengan

\footnotetext{
${ }^{12}$ Bernard L. Tanya dkk, 2010, Teori Hukum (Strategi tertib Manusia Lintas Ruang dan Generasi), Genta Publishing, Yogyakarta, h. 31.
} 
membentuk dan menunjuk aparat-aparat tertentu yang bertugas untuk membina dan mengawasi ketaatan perokok pada Kawasan Tanpa Rokok. Keterlibatan Satuan Polisi Pamong Praja sebagai Penegak Peraturan Daerah. Terkait tugas pokok dan fungsi Satuan Polisi Pamong Praja (Satpol PP) adalah sebagai penegak Peraturan Daerah maka Satpol PP mempunyai kontribusi yang besar dalam hal pengawasan Peraturan Daerah Kawasan Tanpa Rokok. Dinas Kesehatan dan Satuan Polisi Pamong Praja berkoordinasi dengan SKPD lainnya wajib melakukan inspeksi dan pengawasan ke seluruh gedung di wilayah kerjanya. Ini artinya, pengawasan yang dapat dilakukan oleh Satpol PP terkait kawasan tanpa rokok cukup luas yaitu pada seluruh gedung wilayah kerja dari Satpol PP Kota Yogyakarta.

Sesuai dengan pengamatan di lapangan bahwa masih banyaknya ditemukan pelanggaran Kawasan Tanpa Rokok, kaitan antara tim penegak dan pengaturan kawasan tanpa rokok sangat erat dan harus seimbang. Jika pelanggaran masih banyak ditemukan artinya ada beberapa faktor yang menyebabkan hal tersebut terjadi. Jika secara hukum sudah jelas namun penegakan baik secara pembinaan dan pengawasannya masih kurang maka faktor penegak hukum merupakan salah satu penyebab masih banyaknya pelanggaran mengingat mentalitas petugas penegak hukum dalam melakukan tugasnya sangat penting, kalau dari segi peraturannya sudah baik, namun dari segi kualitas penegaknya masih kurang baik maka akan ada masalah yang disebabkan oleh ketidakseimbangan tersebut.

Upaya preventif yang ketiga dalam menegakkan sanksi administratif terhadap pelanggaran kawasan tanpa rokok di Kota Yogyakarta selanjutnya ialah dengan menggunakan strategi-strategi yang termuat didalam aturan-aturan terkait Kawasan Tanpa Rokok di Kota Yogyakarta itu sendiri.

\section{1) Strategi Berdasarkan Tempat}

Strategi penegakan Peraturan Daerah Kawasan Tanpa Rokok berdasarkan tempat dirasa sudah cukup baik karena penentuan penerapan pemasangan tanda-tanda dilarang merokok sudah dominan diaplikasikan oleh pimpinan badan setiap area-area yang dilarang untuk merokok termasuk di tempat kerja seperti di Dinas Kesehatan Kota Yogyakarta. Namun dalam penerapannya, strategi ini bergantung dengan bagaimana metode pembinaan pengawasan oleh Tim Khusus Kawasan Tanpa Rokok terhadap pimpinan badan/usaha kawasan tanpa rokok untuk memasang tanda kawasan tanpa rokok agar dapat memastikan jika metode-metode ini berjalan sesuai dengan yang diharapkan Peraturan Daerah Kawasan Tanpa Rokok.

\section{2) Strategi Berdasarkan Metode Pembinaan dan Pengawasan}

Strategi berdasarkan metode pembinaan dan pengawasan adalah strategi meningkatkan dayaguna Peraturan Daerah Kawasan Tanpa Rokok dengan cara memanfaatkan proses pembinaan dan pengawasan sebagai media penunjang efektivitas kawasan tanpa rokok. Kelemahan dari strategi ini adalah bagi kawasan-kawasan besar yang tergolong sebagai kawasan tanpa rokok seperti tempat-tempat umum semacam 
pasar. Tempat seperti ini akan sulit dilakukan pengawasan jika hanya melibatkan pimpinan badan untuk mengawasi karena pasar merupakan kawasan yang luas dan pasti terdapat banyak perokok didalamnya. Seharusnya untuk tempat-tempat seperti pasar, Pemerintah dapat memerintahkan Satpol PP dalam melakukan pengawasan kawasan tanpa rokok agar pengawasan dapat dilakukan secara merata diseluruh area-area pasar tersebut. ${ }^{13}$

Sedangkan upaya represif dilakukan dengan melakukan sidak dan pengenaan sanksi bagi yang melanggar. Upaya Represif yang dimaksud adalah mengenai penegakan hukum, menurut Satjipto Rahardjo "penegakan hukum adalah suatu proses untuk mewujudkan keinginan-keinginan hukum (yaitu pikiran-pikiran badan pembuat undang-undang yang dirumuskan dalam peraturan-peraturan hukum) menjadi kenyataan". ${ }^{14}$ Upaya Represif dilakukan oleh Satuan Polisi Pamong Praja Kota Yogyakarta, penegakan hukum di tempat yang ditetapkan sebagai Kawasan Tanpa Rokok khususnya Dinas Kesehatan Kota Yogyakarta dilakukan dengan mengadakan agenda sidak ke kawasan-kawasan tanpa rokok.

Dukungan dari para pegawai yang berada di Dinas Kesehatan Kota Yogyakarta ditunjukkan dengan mematuhi aturan yang berlaku, seperti tidak merokok di tempat khusus merokok. Adapun dukungan para pegawai terhadap pelaksanaan kebijakan ini dengan tidak merokok di sembarang tempat kecuali di tempat yang telah disediakan, meskipun demikian tidak sedikit pula yang melanggar dengan berbagai alasan. Mayoritas pegawai menjadi lebih disiplin untuk tidak merokok di sembarang tempat karena para pegawai kantor yang tidak merokok secara otomatis menjadi contoh bagi pengunjung dan masyarakat umum yang ada di sekitar Dinas Kesehatan. Adapun secara khusus strategi kebijakan yang diterapkan oleh pihak Dinas Kesehatan Kota Yogyakarta dalam rangka pelaksanaan kebijakan tentang Kawasan Tanpa Rokok adalah:

1) Mempertegas sanksi supaya dapat memperkecil jumlah pelanggaran, misalnya sanksi yang ditetapkan oleh Dinas Kesehatan Kota Yogyakarta untuk pegawai kantor maupun pengunjung kantor harus dilakukan sanksi secara tegas tidak hanya teguran lisan saja, sehingga supaya peraturan yang diterapkan dapat dilaksanakan secara maksimal dalam penegakannya.

2) Menyediakan Kawasan Tanpa Rokok (KTR) supaya para perokok aktif merokok pada tempat yang telah disediakan serta para perokok pasif tidak terganggu apabila ada seseorang yang merokok di Dinas Kesehatan Kota Yogyakarta.

3) Memasang tanda larangan merokok di beberapa tempat sebagai peringatan kepada pegawai kantor dan pengunjung kantor yang ingin merokok di lingkungan Dinas Kesehatan Kota Yogyakarta.

\footnotetext{
${ }^{13}$ Yogi Firmansyah, 2017, "Penegakan Sanksi Administrasi dalam Peraturan Daerah Kota Metro Nomor 4 Tahun 2014 tentang Kawasan Tanpa Rokok", (Repository Universitas Lampung), h. 3-5.

${ }^{14}$ Satjipto Raharjo, 1996, Masalah Penegakan Hukum, Sinar Baru, Bandung, h. 24.
} 
Keinginan Pemerintah Kota Yogyakarta untuk mewujudkan kesehatan masyarakat dan lingkungan yang difasilitasi dengan kebijakan kawasan tanpa asap rokok masih jauh dari harapan, karena implementasi kawasan tanpa asap rokok di Kota Yogyakarta belum berjalan sebagaimana ketentuan yang telah ditetapkan, baik para pelaku kebijakan maupun pihak-pihak yang menjadi sasaran kebijakan tersebut (perokok). Lokasi yang telah ditetapkan sebagai kawasan tanpa rokok di Dinas Kesehatan Kota Yogyakarta, dalam kenyataannnya masih terlihat beberapa pegawai masih ada yang merokok tidak pada tempat yang sudah disediakan. Implementasi peraturan daerah dikatakan berhasil jika apa yang diharapkan dari adanya kebijakan tersebut dapat diraih, yang dicapai melalui pelaksanaan yang sesuai dengan ketentuan yang telah ditetapkan. Asumsi yang dapat dibangun bahwa semakin tinggi derajat kesesuaiannya, maka akan semakin tinggi pula peluang keberhasilan kinerja implementasi peraturan daerah untuk menghasilkan out put yang telah digariskan. ${ }^{15}$

Berdasarkan hasil wawancara dengan Ibu drg. Arumi Wulansari, MPH., selaku Kepala Seksi Promosi dan Pemberdayaan Masyarakat di Dinas Kesehatan Kota Yogyakarta bahwa dalam penerapan Kawasan Tanpa Rokok di Dinas Kesehatan Kota Yogyakarta masih ditemukan kendala dalam penerapannya yaitu:

1) Kurangnya sosialisasi

Entinsitas sosilisasi pelarangan merokok pada bebarapa kawasan tanpa asap rokok di Kota Yogyakarta tidak sebanding dengan entinsitas iklan rokok yang dilakukan para produsen rokok. Akibatnya, banyak pimpinan lembaga-lembaga yang ada di Kota Yogyakarta, seperti lembaga perguruan tinggi, tempat ibadah, lembaga kursus, sarana olah raga, dan pimpinan lembaga lainnya sebagai kawasan tanpa asap rokok, yang tidak mengetahui keberadaan kebijakan Kawasan Tanpa Rokok yang tertuang dalam Peraturan Daerah Kota Yogyakarta Nomor 2 Tahun 2017 tentang Kawasan Tanpa Rokok. ${ }^{16}$ Pelanggaran masih dilakukan oleh para pegawai di Dinas Kesehatan Kota Yogyakarta karena kurangnya sosialisasi mengenai peraturan tersebut sehingga peraturan daerah tersebut belum berjalan sebagaimana mestinya.

2) Kurangnya kepatuhan masyarakat

Kepatuhan masyarakat menjadi hal yang utama dalam terlaksananya Peraturan Daerah terkait Kawasan Tanpa Rokok. Jika tidak ada kepatuhan dari masyarakat setempat maka Peraturan Daerah tidak dapat berjalan sebagaimana mestinya. Sudah banyak yang patuh untuk tidak merokok di sembarang tempat. Namun, pegawai maupun pengunjung kantor belum mentaati sepenuhnya peraturan tersebut.

3) Sarana yang belum memadai

\footnotetext{
15 Tangkilisan, 2004, Strategi Pengembangan Sumber Daya Manusia Birokrasi Publik, YPAPI, Yogyakarta, h. 31.

16 Winengan, 2017, “Implementasi Kebijakan Kawasan Tanpa Rokok di Kota Mataram”, Jurnal Ilmu Administrasi, Vol. 14, No. 1, h. 13.
} 
Sarana merupakan segala sesuatu yang dapat dipakai sebagai alat dalam mencapai maksud dan tujuan, yang berupa alat maupun media. Dalam hal ini sarana yang dibutuhkan salah satunya adalah area khusus bagi perokok yang ingin merokok. Namun, fasilitas tersebut belum dapat disediakan sepenuhnya di beberapa tempat yang sudah di tetapkan sebagai Kawasan Tanpa Rokok sebagaimana diatur dalam Peraturan Daerah tentang Kawasan Tanpa Rokok. Ketersediaan sarana merupakan hal yang penting demi keberhasilan isi tujuan kebijakan Peraturan Daerah Kota Yogyakarta Nomor 2 Tahun 2017 tentang Kawasan Tanpa Rokok. Sudah ada sarana pendukung Peraturan Daerah Kawasan Tanpa Rokok di Dinas Kesehatan Kota Yogyakarta, yaitu berupa tempat khusus bagi seseorang yang ingin merokok.

4) Sanksi yang kurang tegas dari aparat penegak hukum

Perlu adanya sanksi tegas yang diberikan kepada masyarakat yang melanggar peraturan Kawasan Tanpa Rokok. Ringannya hukuman berdampak pada semakin besarnya pelanggaran karena hukuman yang diberikan tidak memberikan efek jera bagi seseorang yang melanggarnya. Tanpa adanya sanksi yang tegas dan bersifat memaksa, maka perubahan perilaku sulit diwujudkan. Sanksi penegakan Kawasan Tanpa Rokok saat ini baru sebatas teguran lisan saja dan belum dilakukan penegakan secara sepenuhnya. $^{17}$

Kebijakan Kawasan Tanpa Rokok merupakan pembatasan ruang tempat untuk tidak boleh merokok dalam mendorong terbangunnya budaya disiplin bagi perokok aktif atas bahaya dan dampaknya bagi kesehatan. Dengan adanya kebijakan Kawasan Tanpa Rokok diharapkan dapat melindungi orang-orang yang tidak merokok dan mewujudkan lingkungan yang bersih, sehat dan bebas asap rokok. Salah satu menentukan keberhasilan dari kebijakan Kawasan Tanpa Rokok ini adalah adanya respon yang positif/negatif yang ditunjukkan oleh masyarakat dalam bersikap akan menentukan keberlangsungan jalannya peraturan tersebut. ${ }^{18}$

Berbagai tanda larangan untuk tidak merokok, ruangan khusus untuk merokok merupakan salah satu fasilitas yang disediakan oleh Pemerintah Kota Yogyakarta sehingga para perokok aktif dapat merokok dan asap yang ditimbulkan dari para perokok terebut tidak mengganggu para pengunjung yang berada di Dinas Kesehatan Kota Yogyakarta. Namun, di tempat lain yang ditentukan dalam peraturan daerah banyak yang belum disediakan ruangan khusus merokok karena terkendala oleh keterbatasan anggaran. Kerja sama antara pemerintah dan masyarakat secara menyeluruh, terpadu dan berkesinambungan sangatlah penting. Diperlukan kesadaran, kemauan dan kemampuan pemerintah dan masyarakat untuk mencegah penggunaan

\footnotetext{
${ }^{17}$ Hasil wawancara dengan responden drg. Arumi Wulansari, MPH., selaku Kepala Seksi Promosi dan Pemberdayaan Masyarakat di Dinas Kesehatan Kota Yogyakarta, pada hari Kamis tanggal 30 April 2020, pukul 11.00 WIB.

18 Komang Evan Riana, 2019, "Sikap Masyarakat Terhadap Kebijakan Kawasan Tanpa Rokok", (Repository Universitas Lampung), h. 31.
} 
rokok baik yang secara langsung atau tidak langsung mempengaruhi kesehatan. ${ }^{19}$ Aspekaspek penghambat Implementasi kebijakan kawasan tanpa rokok antara lain: ${ }^{20}$

\section{1) Komunikasi}

Implementasi kebijakan mesti didukung baik oleh pemerintah, swasta dan juga masyarakat. Masyarakat berperan sebagai kelompok sasaran yang juga harus mendukung implementasi kebijakan kawasan tanpa rokok di Dinas Kesehatan Kota Yogyakarta. Perlunya kesadaran masyarakat untuk patuh terhadap kebijakan yang ada. Perlunya Komunikasi yang baik terhadap kelompok sasaran seperti sosialisasi dan pembinaan terhadap masyarakat, apakah sosialisasi tersebut berpengaruh besar terhadap tingkat kepatuhan masyarakat terhadap peraturan kawasan tanpa rokok tersebut.

Pegawai kantor sudah mengetahui adanya kebijakan tersebut tetapi tidak mengetahui isi atau batasan-batasan untuk tidak merokok di Kawasan Tanpa Rokok. Dalam hal penyampaian dinilai masih kurang karena dari pihak dinasnya sendiri masih menyampaikan secara Top Down akhirnya tidak semua masyarakat mengetahui peraturan tersebut. Kemudian tidak semua pegawai dapat secara menegur pelanggar secara terus-menerus karena setiap pegawai juga tidak bisa meninggalkan tugas pokoknya masing-masing.

\section{2) Sumber Daya}

Sumber daya yang dimaksud adalah ketersediaan sarana dan prasarana dalam implementasi peraturan Kawasan Tanpa Rokok, serta sumberdaya manusia sebagai pelaksana implementasi kebijakan. Sumberdaya manusia yang berkualitas baik itu dalam badan pelaksana kegiatan maupun masyarakat sebagai sasaran peraturan akan semakin mendukung dalam implementasi peraturan tersebut. Kemampuan sumberdaya untuk melaksanakan kebijakan ,sumber dana dan ketesediaan sarana dan prasarana untuk mendukung keberhasilan implementasi kebijakan kawasan tanpa rokok. Dinas Kesehatan Kota Yogyakarta sudah memiliki tim khusus satuan tugas (satgas) penegak dan pengawas kawasan tanpa rokok. Selain itu sumber daya lainnya seperti adanya anggaran dana serta fasilitas-fasilitas penunjang kawasan tanpa rokok seperti tempat khusus untuk merokok, papan informasi larangan merokok, poster larangan merokok, surat edaran larangan merokok dan lain-lain yang menunjang kawasan tanpa rokok sudah diterapkan di Dinas Kesehatan Kota Yogyakarta.

\section{3) Disposisi Sikap}

Sikap pelaksana harus memiliki pengetahuan, keterampilan, proses maupun teknik yang bisa memperlancar keberhasilan suatu tugas atau pekerjaan yang dibebankan kepadanya. Pelaksana harus pahap terhadap kebijakan Kawasan Tanpa Rokok yang

\footnotetext{
${ }^{19}$ Kwe Fei Lie Shirley,dkk, 2016, "Kebijakan Tentang Pedoman Kawasan Tanpa Rokok Dikaitkan dengan Asas Manfaat", Jurnal Hukum Kesehatan, Vol. 2, No. 1, h. 105.

20 Ricky Fernando, dkk, 2016, "Implementasi Kebijakan Kawasan Tanpa Rokok di Puskesmas Pandanaran Kota Semarang”, Jurnal of Public Policy and Management Review, Vol. 5, No. 2, h. 11-12.
} 
berlaku. ${ }^{21}$ Pemahaman Petugas Pengawasan Kawasan Tanpa Rokok di Dinas Kesehatan Kota Yogyakarta sudah dimengerti dengan baik dan dapat menegur pengunjung yang melanggar. Tetapi seperti yang dijelaskan oleh pihak Dinas Kesehatan Kota Yogyakarta bahwa Perda ini masih belum ditegakkan secara maksimal sehingga masih belum ada efek jera bagi para pelanggarnya. Butuh keberanian dan kepedulian terhadap lingkungan sekitar untuk dapat menegur orang yang merokok di sembarang tempat atau Kawasan Tanpa Rokok.

Diketahui bahwa hasil yang telah dicapai dari Implementasi Peraturan Daerah Kota Yogyakarta Nomor 2 Tahun 2017 tentang Kawasan Tanpa Rokok di Dinas Kesehatan Kota Yogyakarta sudah dirasakan. Mereka yang merokok di dalam gedung sudah berkurang. Para pegawai instansi cukup kooperatif dan mendukung pelaksanaan Peraturan Daerah Kawasan Tanpa Rokok. Hal ini juga didukung dengan adanya tempat khusus merokok dan banner yang berbunyi Kawasan Tanpa Rokok. Pelaksana Peraturan Daerah Kawasan Tanpa Rokok juga melibatkan stakeholder baik dari luar maupun dari dalam harus terlibat, dari Organisasi Masyarakat, Majlis Ulama Indonesia, Akademisi, Tokok Masyarakat serta masyarakat umum berhak untuk mengingatkan Peraturan Daerah Kawasan Tanpa Rokok.

Penerapan Kawasan Tanpa Rokok secara konsisten diharapkan dapat meningkatkan derajat kesehatan masyarakat terutama terkendalinya faktor risiko penyakit dan kematian yang disebabkan oleh rokok, dan meningkatnya budaya msyarakat dalam berperilaku hidup bersih dan sehat. Selain itu, akan meningkatkan citra (pandangan) yang baik dari masyarakat umum terhadap daerah dan pemerintahnya dengan meningkatnya kedisiplinan, ketertiban dan kepatuhan pada peraturan. Dari aspek lingkungan, penerapan kawasan tanpa rokok akan berdampak pada meningkatnya kualitas udara, terutama kualitas udara dalam ruang. Dalam bidang ekonomi, akan mampu meningkatkan tingkat ekonomi keluarga karena berkurangnya belanja rokok, terutama pada keluarga miskin. Demikian juga bagi pemerintah setempat akan mengurangi pengeluaran belanja pemerintah daerah untuk pembiayaan kesehatan dalam penanggulangan penyakit akibat rokok. ${ }^{22}$

\section{Simpulan}

Dinas Kesehatan Kota Yogyakarta merupakan tempat kerja atau area yang dinyatakan dilarang untuk kegiatan merokok atau kegiatan memproduksi, menjual, mengiklankan dan/atau mempromosikan produk tembakau. Dinas Kesehatan Kota Yogyakarta melakukan 2 cara dalam menerapkan Peraturan Daerah tentang Kawasan Tanpa Rokok yaitu Sosialisasi dan Penerapan Peraturan. Sosialisasi merupakan hal yang

\footnotetext{
${ }^{21}$ Ricky Fernando, dkk, 2016, "Implementasi Kebijakan Kawasan Tanpa Rokok di Puskesmas Pandanaran Kota Semarang", Jurnal of Public Policy and Management Review, Vol. 5, No. 2, h. 5- 6.

${ }^{22}$ Anonim: Memahami Lebih Dalam tentang Kawasan Tanpa Rokok (KTR), https://bulelengkab.go.id/detail/artikel/memahami-lebih-dalam-tentang-kawasan-tanpa-rokok-ktr-77, diakses pada tanggal 9 Oktober 2020, Pukul 11.00 WIB.
} 
penting dalam penerapan peraturan daerah. Masyarakat perlu dilibatkan dalam seluruh proses pengembangan Peraturan Daerah Kawasan Tanpa Rokok untuk memahami bahaya mengisap asap rokok. Dinas Kesehatan Kota Yogyakarta sudah menerapkan Peraturan Daerah Kota Yogyakarta Nomor 2 Tahun 2017 tentang Kawasan Tanpa Rokok dan sudah disediakan beberapa tempat khusus untuk merokok, namun masih banyak pegawai maupun pengunjung kantor yang belum mengetahui Peraturan Daerah tersebut dan masih ada yang merokok tidak pada tempat khusus merokok yang disediakan. Pemerintah Kota Yogyakarta telah melakukan upaya-upaya penegakan peraturan berupa upaya represif dan upaya preventif yang dilakukan oleh Dinas Kesehatan Kota Yogyakarta dan Satuan Polisi Pamong Praja Kota Yogyakarta. Upaya preventif yaitu berupa pencegahan pelanggaran Kawasan Tanpa Rokok dengan kegiatan berupa sosialisasi, pembinaan dan pemberian pedoman, serta monitoring dan evaluasi. Sedangkan upaya represif dilakukan dengan melakukan sidak dan pengenaan sanksi bagi yang melanggar.

Sudah ada Tim Monitoring dan Evaluasi dalam implementasi kawasan tanpa rokok. Pengawasan kawasan tanpa rokok juga diawasi dari perwakilan masyarakat, perwakilan organisasi masyarakat, perwakilan akademisi, perwakilan Majelis Ulama Indonesia, perwakilan Pemberdayaan dan Kesejahteraan Keluarga, dan Muhammadiyah Tobacco Control Center. Dukungan dari para pegawai yang berada di Dinas Kesehatan Kota Yogyakarta ditunjukkan dengan mematuhi aturan yang berlaku, seperti tidak merokok di tempat khusus merokok. Namun, masih ada pegawai yang belum mematuhi aturan tersebut. Strategi kebijakan yang diterapkan oleh pihak Dinas Kesehatan Kota Yogyakarta yaitu mempertegas sanksi bagi para pelanggar, menyediakan tempat khusus merokok dan memasang tanda larangan merokok di beberapa tempat. Penerapan Kawasan Tanpa Rokok di Dinas Kesehatan Kota Yogyakarta masih ditemukan kendala dalam penerapannya yaitu kurangnya sosialisasi, kurangnya kepatuhan masyarakat, sarana yang belum memadai dan sanksi yang kurang tegas dari aparat penegak hukum. Diketahui bahwa hasil yang telah dicapai dari Implementasi Peraturan Daerah Kota Yogyakarta Nomor 2 Tahun 2017 tentang Kawasan Tanpa Rokok di Dinas Kesehatan Kota Yogyakarta sudah dirasakan. Mereka yang merokok di dalam gedung sudah berkurang. Para pegawai instansi cukup kooperatif dan mendukung pelaksanaan Peraturan Daerah Kawasan Tanpa Rokok.

\section{Daftar Pustaka}

\section{Buku}

Bernard L. Tanya dkk, 2010, Teori Hukum (Strategi tertib Manusia Lintas Ruang dan Generasi), Yogyakarta: Genta Publishing

M. Syamsudin, 2007, Operasional Penelitian Hukum, Edisi pertama, Jakarta: Raja Grafindo persada 
Satjipto Raharjo, 1996, Masalah Penegakan Hukum, Bandung: Sinar Baru

Tangkilisan, 2003, Kebijakan Publik yang Membumi, Konsep, Strategi dan Kasus, Yogyakarta: Lukman Offset dan YPAPI

Tangkilisan, 2004, Strategi Pengembangan Sumber Daya Manusia Birokrasi Publik, Yogyakarta: YPAPI

Widyastuti Soerojo, dkk, 2011, Pengawasan/Penegakan Hukum Kawasan Tanpa Rokok, Palembang: TCSC-IAKMI

\section{Jurnal}

Ade Resty Ambar Wati, (2017), "Penerapan Kawasan Tanpa Rokok berdasarkan Peraturan Daerah Kota Metro Nomor 4 Tahun 2014”, Jurnal Fakultas Hukum Universitas Lampung, Volume 4, Nomor 2

Kwe Fei Lie Shirley,dkk, (2016), "Kebijakan Tentang Pedoman Kawasan Tanpa Rokok Dikaitkan Dengan Asas Manfaat”, Jurnal Hukum Kesehatan, Volume 2, Nomor 1

Meysi Ariska, (2017), "Implementasi Peraturan Daerah Kabupaten Bintan Nomor 1 Tahun 2016 tentang Kawasan Tanpa Rokok”, Jurnal Ilmu Administrasi Negara, Volume 5, Nomor 1

Ricky Fernando, dkk, (2016), "Implementasi Kebijakan Kawasan Tanpa Rokok di Puskesmas Pandanaran Kota Semarang", Jurnal of Public Policy and Management Review, Volume 5, Nomor 2

Yana Agus Setianingsih, dkk, (2016), "Pelaksanaan Kebijakan Kawasan Tanpa Rokok (KTR) Sebagai Bagian Dari Perilaku Hidup Bersih dan Sehat (PHBS) di Lingkungan Pendidikan (Studi Kasus Pada STIKES di Kota Semarang)", Jurnal Hukum Kesehatan, Volume 1, Nomor 1

Winengan, (2017), “Implementasi Kebijakan Kawasan Tanpa Rokok di Kota Mataram”, Jurnal Ilmu Administrasi, Volume 14, Nomor 1

\section{Skripsi}

A.Ikram Rifqi, 2017, "Implementasi Peraturan Daerah Kota Makassar Nomor 4 Tahun 2013 tentang Kawasan Tanpa Rokok di Universitas Hasannudin”, (Repository Universitas Hasannudin Makassar)

Amalia Lathifah, 2018, "Implementasi Peraturan Walikota Yogyakarta Nomor 2 Tahun 2015 tentang Kawasan Tanpa Rokok", (Repository Universitas Islam Negeri Sunan Kalijaga Yogyakarta) 
Andi Mariani, 2009, "Pemberlakuan Larangan Merokok di Tempat Umum dan Hak Atas Derajat Kesehatan Optimal”, (Program Pascasarjana Magister Hukum Kesehatan Universitas Katolik Soegijapranata Semarang)

Komang Evan Riana, 2019, "Sikap Masyarakat Terhadap Kebijakan Kawasan Tanpa Rokok", (Repository Universitas Lampung)

Yogi Firmansyah, 2017, "Penegakan Sanksi Administrasi dalam Peraturan Daerah Kota Metro Nomor 4 Tahun 2014 tentang Kawasan Tanpa Rokok", (Repository Universitas Lampung)

\section{Wawancara}

drg. Arumi Wulansari, MPH., wawancara pribadi dengan Kepala Seksi Promosi dan Pemberdayaan Masyarakat di Dinas Kesehatan Kota Yogyakarta, 13 April 2020.

\section{Perundang-undangan}

Undang-Undang Nomor 32 Tahun 2004 tentang Pemerintahan Daerah

Peraturan Bersama Menteri Kesehatan dan Menteri Dalam Negeri Nomor 7 Tahun 2011 tentang Pedoman Pelaksanaan Kawasan Tanpa Rokok

Peraturan Daerah Kota Yogyakarta Nomor 2 Tahun 2017 tentang Kawasan Tanpa Rokok

\section{Internet}

Anonim: Memahami Lebih Dalam tentang Kawasan Tanpa Rokok (KTR), diakses pada $\begin{array}{llllll}\text { tanggal } 9 & \text { Oktober } 2020 \text { pukul } 11.00 \text { WIB pada }\end{array}$ https://bulelengkab.go.id/detail/artikel/memahami-lebih-dalam-tentang-kawasantanpa-rokok-ktr-77 